\title{
Some Problems in Recording and Analyzing South African English Vocabulary Using Non-South African Texts (The Experiences of an Outsider)
}

David L. Gold, Jewish English Archives, New York

\begin{abstract}
This article describes some problems in collecting and studying South African English vocabulary on the basis of non-South-African texts faced by a linguist who is a native speaker of American English. The questions are thus: Are non-South-African texts just as reliable as South African texts? More reliable? Less reliable? And is a linguist who is a native speaker of a different variety of English just as reliable as a native? More reliable? Less reliable? It is suggested here that the best way of studying a language, if possible, is by having both insiders and outsiders look at the material.
\end{abstract}

Keywords: ABBREVIATIONS, AFRICAN LANGUAGES, AFRIKAANS, AMERICAN ENGLISH, AUSTRALIAN ENGLISH, BLACK ENGLISH, BRITISH ENGLISH, CANADIAN ENGLISH, CAPITALIZATION, CAREFUL USE OF PRIMARY AND SECONDARY SOURCES, CONVERGENCE, DEFINITIONS, DICTIONARIES, DIFFERENTIAL DICTIONARIES, DUTCH, ENGLISH, ETYMOLOGY, FAMILY NAMES, FOLK ETYMOLOGY, FRENCH, GERMAN, HEBREW, INITIALISMS, LATIN, LEXICOGRAPHY, MISPRINTS, NONCE FORMS, OVERDEFINITION, PERSONAL NAMES, PLACE NAMES, POSTAL TERMS, PREPOSITIONS, PRODUCTIVIZATION, REFLEXIVE PRONOUNS, SLANG, SLIPS OF THE TONGUE, SOUTH AFRICAN ENGLISH, SPELLING, STATUS AND USAGE LABELS, SURFERS' TERMS, TEAMWORK, UNDERDEFINITION, YIDDISH, ZOOLOGICAL TERMS

Opsomming: Enkele probleme by die optekening en analise van die SuidAfrikaanse Engelse woordeskat uit nie-Suid-Afrikaanse tekste (Die ervarings van ' $n$ buitestaander). Hierdie artikel beskryf enkele probleme in die versameling en bestudering van die Suid-Afrikaanse Engelse woordeskat uit nie-Suid-A frikaanse tekste waarmee 'n linguis wat 'n moedertaalspreker van Amerikaanse Engels is, te doen kry. Die vrae is dus: Is nie-Suid-Afrikaanse tekste net so betroubaar soos Suid-Afrikaanse tekste? Betroubaarder? Minder betroubaar? $E n$ is ' $n$ linguis wat ' $n$ moedertaalspreker van ' $n$ ander variëteit van Engels is, net so betroubaar soos ' $n$ moedertaalspreker? Betroubaarder? Minder betroubaar? Hier word aan die hand gedoen dat die beste manier om ' $n$ taal te bestudeer, is om, waar moontlik, sowel inheemse as uitheemse sprekers na die materiaal te laat kyk. 
Sleutelwoorde: AFKORTINGS, AFRIKAANS, AFRIKATALE, AMERIKAANSE ENGELS, AUSTRALIESE ENGELS, BRANDERRYTERME, BRITSE ENGELS, DEFINISIES, DIFFERENSIëLE WOORDEBOEKE, DRUKFOUTE, DUTTS, ENGELS, ETIMOLOGIE, FRANS, GELEENTHEIDSWOORDE, HEBREEUS, HOOFLETTERGEBRUIK, JIDDISJ, KANADESE ENGELS, KONVERGENSIE, LATYN, LEKSIKOGRAFIE, NEDERLANDS, ONDERDEFINIËRING, OORDEFINIëRING, PERSOONSNAME, PLEKNAME, POSTERME, PRODUKTIEFMAKING, SLENG, SOÖLOGIETERME, SPANWERK, SPELLING, STATUS- EN GEBRUIKSMERKERS, SUID-AFRIKAANSE ENGELS, SWART ENGELS, VANNE, VERSIGTIGE GEBRUIK VAN PRIMêRE EN SEKONDêRE BRONNE, VERSPREKINGS, VOLKSETIMOLOGIE, VOORLETTERWOORDE, VOORSETSELS, WEDERKERENDE VOORNAAMWOORDE, WOORDEBOEKE

\section{Contents}

1. Introduction

2. Material gleaned from American and other non-South-African sources which does not seem to require discussion

3. Material gleaned from American and other non-South-African sources which requires discussion

4. Conclusions

\section{Introduction}

Peering at the fishbowl from the outside has certain advantages and disadvantages (Gold 1986 and Rosenstein 1993), just as looking at it from the inside has its pluses and minuses. As a non-South-African linguist with a minor interest in South African English and Afrikaans who has never been to South Africa, has never heard a word of Afrikaans, has probably heard in all not more than two hours of South African English, and has access to only a few written sources, I could not be more of an outsider.

Naturally, then, one must be cautious in one's choice of research topics and one must be certain that the South African editors of one's publications do their job by scrupulously criticizing every draft before it gets into print. That would have been possible here, but that would have defeated the purpose of this article, which is not so much to answer questions or solve problems by presenting a finished list of items meriting inclusion in a differential dictionary of South African English as it is to ask questions, present problems, raise issues, and to illustrate the advantages and disadvantages of research carried out by 
an outsider (however, since D.C. Hauptfleisch was kind enough to react to sample entries which I had sent him from an earlier draft of this article, his remarks, valuable as always, are given here for the benefit of others too).

Since South African English is an outgrowth of British English, a differential dictionary of South African English should be written by comparing it to British English. For that purpose, it would be more advantageous to be a speaker of British than American English. I know little specifically British English, but the task of comparing it to South African English is possible nonetheless, though harder.

First, therefore, any South African usage which strikes an American ear as unusual has to be checked against British English. If it is British too, it is disregarded. For instance, the South African English labor term go-slow sounds odd to the American ear (American English has slowdown), but since British English has go-slow, the word is not a South-Africanism. Similarly, South African English has ballot paper whereas current American English has ballot (even in the concrete sense of 'slip of paper...'), but ballot paper is also British English.

Second, one must be on the lookout for the converse of the foregoing situation: South African English and American English may agree with each other and be different from British English, in which case a speaker of American English might miss a South African item that should be listed in a differential South African English dictionary which takes British English as its point of comparison.

All descriptivists, whether they are insiders or outsiders, face the problem of determining the currency of an item. Hearing a usage for the first time, we cannot tell where it belongs along the continuums of frequency and range. Is it a nonce form or a slip of the tongue - said or written but once, never again to be encountered? Or it is a usage frequent among all members of the speech community under investigation? Or does it occupy some point between those two extremes? All we can do is record it and try to see whether it turns up again (see mbube in section 3). A number of such usages, heard from South Africans interviewed on American television, are noted below. It need not be emphasized that it is in unrehearsed speech that nonce forms and slips of the tongue are most frequent.

More problems too are raised below.

Unless otherwise noted, none of the South African English usages given here is in Branford and Branford 1991.

2. Material gleaned from American and other non-South-African sources which does not seem to require discussion

Alex informal 'Alexandra (a township near Johannesburg)' [clipping of Alexandra, probably inspired by Alex, a pet form of the English female given name Alexandra]. 
AMC 'African Moderates Congress (a political party established just before the April 1994 elections)' [letterword; the African National Congress, informally known by the initialism ANC, charged that AMC was chosen to confuse voters and mislead them into voting for the African Moderates Congress: since ANC and AMC are similar but ANC is far better known, voters, the ANC noted, might inadvertently cast their ballot for the AMC thinking they were voting for the ANC; the ANC also charged that Clarence Makwetu was chosen to head the Pan African Congress only because he looks like Nelson Mandela and his picture on the ballot paper could thus mislead voters into thinking they were voting for Mandela].

the Black Napoleon epithet 'King Shaka of the Zulus'.

the Black Pimpernel nickname 'Nelson Mandela (when he was head of the Spear of the Nation)' [in allusion to the Scarlet Pimpernel]. See the Old Man below.

by the house 'at home'. E.g., "He's by the house" [translation of Afrikaans by die huis].

do a Winnie 'to make a remarkable political recovery' [in allusion to Winnie Mandela's recovery of political power after falling from grace when she was implicated in the death of two South Africans].

hot 'characterized by violence'. Applied to a populated area, especially a township.

independence Black 'attainment of majority rule in South Africa'. Synonym of uhuru.

the Old Man affectionate nickname 'Nelson Mandela (since his release from prison)'. Analogs are German der Alte, the nickname of Konrad Adenauer in his later years, and Israeli Hebrew hazaken, the nickname of David BenGurion after his retirement from politics. See the Black Pimpernel above.

Old Port Elizabeth 'the White neighborhoods of Port Elizabeth'. Keller 1994j has: "'Old Port Elizabeth,' as everyone calls white Port Elizabeth." See motor city and shack town in section 3 for two usages from the same article which do require discussion.

PWV 'name of one of the nine provinces established in South Africa by the interim constitution' [initialism of Pretoria, Witwatersrand, Vereeniging].

reintegration 're-incorporation of the homelands into South Africa'. 
3. Material gleaned from American and other non-South-African sources which requires discussion

a / an

Discussion: South African English and American English may differ in the use of the indefinite article. Keller 1994h quotes Derek Keys, the Finance Minister in both the De Klerk and Mandela cabinets, as saying "The realization of many of our objectives for a fair and equal treatment of all our people will not be possible unless we succeed in avoiding high inflation in the economy." Although the indefinite article in that sentence might be possible in American English, to an American ear it sounds better without it.

\section{administrator}

Discussion: Various non-South-African sources give the title of the head of a South African province as administrator, governor, premier, provincial administrator, and provincial premier. Either certain sources are in error or the title has changed over the years. For comparative purposes, let it be noted that at the head of an American state is a governor, of a Canadian province a premier, and of Canada the prime minister.

Remark from D.C. Hauptfleisch: Volgens die bestaande Suid-Afrikaanse grondwet het elk van die bestaande vier provinsies ' $n$ administrateur (administrator) aan die hoof. Na die inwerkingtreding van die nuwe oorgangsgrondwet sal 'n premier (Afrikaans en Engels) die hoof wees van elk van die nege nuwe provinsies. Tydens die bewind van die VOC aan die Kaap en die Britse bewind aan die Kaap en in Natal was 'n goewerneur (governor) aan die hoof. Van Uniewording (1910) tot Republiekwording (1961) het 'n goewerneur-generaal (governor-general) as staatshoof die Britse koning(in) in SuidAfrika verteenwoordig.

Discussion: It would thus seem that provincial administrator and provincial premier are unofficial terms, used to make administrator and premier more specific, just as in American English governor may be expanded to state governor, which is not official or widely used but readily formed when explicitness is required ("If localities resist unification, the law requires the newly elected provincial premier, similar to a state governor, to [...]" [Clines 1994c]). It would also seem that South African English and Afrikaans premier to designate the head of one of the nine new provinces is a borrowing from Canadian English; if so, that is presumably the first and only South African English item of that origin.

akrinkle

Discussion: Francis $X$. Clines writes: "The fresh victors [in the parliamentary elections of April 1994, D.L.G.] exchanged their cabalistic niceto-see-you handshakes - with eyes akrinkle and left hand cupping the adversary's right elbow - as political sincerity was hand-cranked into the 
day's dominant theme, reconciliation" (Clines 1994b). Akrinkle is obviously like ablaze, agape, agleam, aglow, astride, and awry, but I do not recognize akrinkle or "krinkle. If this is a misprint for *acrinkle, I find no sense of crinkle which would fit here. Might this word, however it should be spelled, be a South-Africanism, which Clines, an American reporter, picked up during his visit to South Africa? Or might this be an American usage absent in South African English?

\section{all-race and all-racial}

Discussion: The printed and spoken media in the United States characterized the South African elections of April 1994 as all-race, all-racial, multiracial / multi-racial, nonracial / non-racial, or panracial / pan-racial elections and they noted that the new government would promote nonracial education. Although speakers of American English readily understand both all-race and all-racial, they do not exist in that variety of English and it is a moot point whether any such speaker would spontaneously coin either of them (to my ear they sound a bit non-American). Since all-race and all-racial sound a bit odd coming from speakers of American English, my guess is that American reporters picked up these words in South Africa; if so, these must be South African English usages.

\section{also}

Discussion: Chidambaran 1994 quotes Louis Meltz, a White South African, possibly a Jew, living in the United States: "I will not go back, and I am sure many other whites also won't." Standard English usage is "many other whites won't either." Yiddish has oykh / oykhet (literally 'also') here ("kh'vel nit tsrikforn, un kh'bin zikher az nokh a sakh vayse veln oykh[et] nit tsrikforn"), but Yiddish is unlikely to be the source of this use of also: even if we assume that the speaker is a Jew, he is young ("a young attorney like me"), hence presumably a native speaker of English, hence someone whose English includes, at the very most, only a few yiddishisms, all of which must be lexical items. Rather, this is presumably an afrikaansism: Joubert 1992 translates he doesn't know either by hy weet ook nie and not that either by ook dit nie.

\section{Bantu knot}

Discussion: Not every English lexeme containing the word Bantu need have been coined in South African English. Bantu knot is one of several Black American English terms which describe various ways in which Black Americans with kinky hair may arrange it (see the illustration), others being African lock, fishtail braid, and Nubian twist. It seems likely that Bantu, African, and Nubian are fanciful, chosen merely to create a link with Africa and not because the knots in question originated in the places named (the phenomenon is not infrequent; cf., e.g., English Jerusalem cherry and Jerusalem cricket, whose designata have nothing whatsoever to do with Jerusalem). A dictionary of 
South African English would list Bantu knot only if it had a category of entries labeled 'item not coined or used in South African English but nonetheless of South African interest'.

See tri-partheid below.

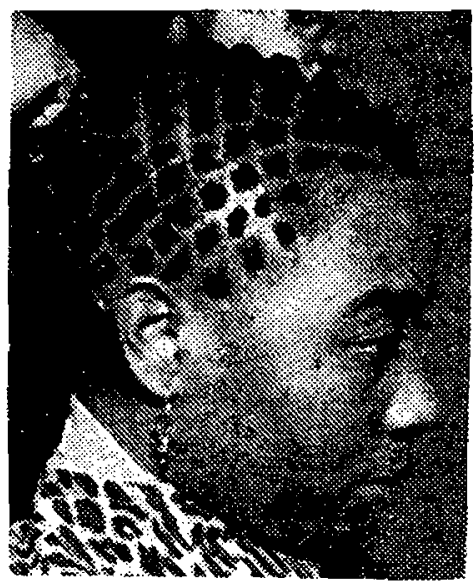

\section{boss}

Discussion: Bill Keller, an American reporter, writes: "'Blacks are not automatically moving out of the way when you walk down the street,' said Andrew Miller, who works for a literacy project in Pretoria, although he noted many black South Africans cannot shake the deferential habit of addressing whites as 'Madam' or 'Boss'" (Keller 1994g). Francis X. Clines, an American reporter, writes: "'Hey, boss! Good boss?' asked a familiar black man outside the government building who, long before apartheid died, had been pumping coins into parking meters for a living so local rulers did not get fined. Today he posed the question regardless of color" (Clines 1994b).

Although South African English does have boss boy 'a man, usu. African, in charge of a gang of mine- or other workers' (Branford and Branford 1991), it is probable that the two South Africans quoted above actually said baas, which Keller and Clines, being speakers of American English, took to be identical to American English boss. Here, then, we see the frequent phenomenon, found in every language, of the unfamiliar being reinterpreted as the familiar (in essence, Keller and Clines folk-etymologized South African English baas as American English boss). We would therefore not want to use those two quotations as evidence for boss as an address form in South African English (see stand on line below for a similar problem).

Keller presumably realized his mistake a few days later, as may be seen from Keller 1994h, where we read: "Mr. Mandela said [in his state-of-thenation speech that] the new tolerance must include an end to the casual racism 
that still permeates work places and social encounters. Blacks will not tolerate being called 'kaffir' or 'boy,' and whites will not be deferred to as 'baas,' he said."

\section{Capetown}

Discussion: In current normative English, some place names end in Town and others end in -town. Thus, although current English as a whole has both spellings, the name of any specific place so ending has by now been standardized one way or the other (for example, Cape Town vs. Grahamstown and Sophiatown). Given that lack of uniformity, we may expect non-natives to use wrong spellings. Indeed, American publications often have Capetown instead of Cape Town. In respect of place names, then, we would be cautious in using non-South-African sources.

In a similar vein, we may note that certain American publications write KwaZulu rather than kwaZulu (the latter being the official spelling in South Africa) because Americans are not used to seeing place names beginning with a lower-case letter. That is not to say that KwaZulu and other such spellings are absent entirely in South African English: South Africa: a World in one Country: Travel Guide mentions the Tourism Association of Natal and KwaZulu (p. 121) and KwaMatiwane (p. 54). ${ }^{1}$

Non-South-Africans may likewise misspell abbreviations. South African usage seems to be only C.T. 'Cape Town', whereas CT is sometimes found in American publications, probably because in recent years the United States Postal System has uniformized the abbreviations of the names of the American states by, inter alia, removing all periods (e.g., NY instead of N.Y.).

And the same may be said of South African personal names. For instance, under the influence of the French "noble" particle de, The New York Times consistently writes Mr. de Klerk (see the quotation securocrat below) and F.W. de Klerk, when in point of fact that is not a French word at all but the Dutch definite article de (Dutch de klerk 'the scribe, the secretary; the cleric [here: member of a minor religious order, permitted to marry]') and the Afrikaans (hence also South African English) custom is to use a lower-case letter only when the name is preceded by a given name or the initial(s) of a given name (thus, Frederik Willem de Klerk, F.W. de Klerk, Mr. Frederik Willem de Klerk, and Mr. F.W. de Klerk, but Mr. De Klerk, "I spoke with De Klerk this morning," etc.).2 Again, we should be careful in using non-South-African

1 The guide bears no date which a layperson can understand, but those in the know will probably be able to infer it from "ISBN 086485 369/6Travel Guide/Eng/92/70 (Reprint)," which appears on the last page. The guide was sent to me by the South African Tourism Board in New York City in May 1994.

D.J. van Schalkwyk tells me that van (as well as van der and van den, de, du, ten, and ter) is the usual spelling in Afrikaans family names, except when they occur without given names or the initials of given names, in which case Van is used (likewise Van der, Van den, De, Du, 
sources to glean South African proper names.

Remark from D.C. Hauptfleisch: Dit is my indruk dat C.T. die gebruiklikste afkorting vir Cape Town is, hoewel CT ook voorkom wanneer afkortingspunte in bepaalde situasies nie gebruik word nie, bv. in vlugroosters. Vergelyk L.A./LA (Los Angeles) en N.Y./NY (New York).

Discussion: D.C. Hauptfleisch's last sentence refers to older and newer American English usage. Years ago, only L.A. and N.Y. were used.

chalk board 'blackboard'.

Discussion: This usage did not turn up in any dictionary of British English consulted, but a thorough investigation of British English (including the interrogation of native speakers) is needed before we may conclude that this usage is a South-Africanism. If it is, we would then look for an etymology (an innovation not due to the influence of any other language? a translation from some language of South Africa?). Current American English seems to have only blackboard, which is frequent in South African English too.3

chocolate contemptuous and offensive 'non-White'.

Discussion: The word is so defined in an American newspaper, but it is not clear whether this is a noun, an adjective, or both. Whether this is a translation of the Afrikaans word for 'chocolate' also needs to be determined.

co-anthem 'each of the two songs, "Die Stem van Suid-Afrika" and "Nkosi Sikelel' iAfrika," which the Interim Constitution of South Africa recognizes as official national anthems'.

Ten, and Ter). If a title precedes, spelling is likewise with a capital letter if given names or their initials are omitted, e.g., Mnr. Van Biljon. For purposes of alphabetization, all elements of the family name are taken into account, though sporadic attempts have been made to disregard these particles and consider only the chief element of the name.

Afrikaans-speakers appear to be extremely sensitive to the question of lower vs. upper case in their family names if we may judge from the fact that several non-South-African speakers of English have told me that Afrikaans-speakers got angry when they used one case instead of another (thus, for example, writing Johan Van Biljon instead of Johan van Biljon). The error, not intentional, in part derives from unfamiliarity with the Afrikaans rules (which are not simple) and in part results from the Afrikaans custom of using all capitals when typing the writer's name at the end of a letter (a frequent custom in bibliographies too). It is impossible to tell from F.W. VAN DER MERWE, for example, whether one, two, or three capitals should be used. The solution is to abandon all-capitals and thus make it crystal-clear to one's addressee what the correct spelling is.

3 No later than 1954 it was determined in the United States that a certain shade of green is easier on the eyes than black, as a result of which boards so colored were introduced into American schools. Some people called them greenboards at the time; I do not know whether that usage caught on. 
Discussion: Several countries, like Belgium, Canada, Luxembourg and Switzerland, have an anthem with official versions in more than one language, but none, so far as I know, has more than one anthem. This word is thus in all likelihood a South African innovation, though since it was found in an American source, we first want to attest its presence in South African English (the American reporter using it might have coined it himself) and only once that was established would we try to see where the word was coined.

Inasmuch as South Africa has three capitals (Pretoria, the administrative capital; Cape Town, the legislative capital; and Bloemfontein, the judicial capital), it would be good to find out whether South African English has *co-capital, which, if it does exist, may be a South African coinage.

Day of the Heroes 'since 1992, the name of the South African national holiday till then called Day of the Vow; it now celebrates not only the voortrekkers but Black South Africans too'.

Discussion: The foregoing definition is based on an account in The New York Times, but it seems unusual, in light of new conditions in South Africa, that only voortrekkers and Blacks would be celebrated. Might it not honor all South African heroes, regardless of ethnicity?

departures hall

Discussion: On 27 April 1994, a reporter speaking on American television from Johannesburg used departures hall to refer to a certain structure at Jan Smuts Airport. He seemed to be a speaker of British rather than South African English, but I am not sure (he was definitely not an American). British usage appears to be departure hall (like departure platform and arrival platform at railways stations). To an American ear, only departure hall sounds familiar (though John F. Kennedy Airport, in New York City, has an International Arrivals Building). It thus remains to be determined whether South African English has departures hall, departure hall, or both.

After the foregoing was written, I found International Arrivals Hall (referring to Jan Smuts Airport) in a South African publication. It is thus clear that South African English has at least arrivals hall and, by implication, departures hall.

\section{Die Stem and Die Stem van Suid-Afrika}

Discussion: I had thought that stem in Die Stem and Die Stem van SuidAfrika had its literal meaning ('voice'), which is the Branfords' understanding too (see Stem, Die in Branford and Branford 1991). Keller 1994f: A14, however, has 'The Call of South Africa' and later articles in The New York Times use that translation too. I suspect that Keller was misinformed (and later copied by other reporters for that newspaper), but we would want an authoritative ruling 
from someone in the know. It is possible that, although the Afrikaans common noun stem means 'voice', the official English translation of the anthem has Call. earlier or later 'sooner or later' [translation of Afrikaans vroeër of later 'idem']

Discussion: Keller 1994i quotes Sampie Terreblanche, a native speaker of Afrikaans: "But earlier or later - and let it not be too late - he will have to make unpopular decisions." From just this single instance of the item, we cannot determine its currency.

exchange $x$ with $y$ 'to substitute $y$ for $x$, replace $x$ by $y$ '.

Discussion: F.W. de Klerk is quoted in The New York Times of 28 April 1993, p. A7, as having said "You'll just exchange one form of suppression with another form of suppression, and one form of liberation movement with another form of liberation movement." General English has exchange with only when the object of with designates one of the exchangers ("exchange posts / seats / places / words / etc. with someone"). Otherwise, exchange takes for ("to exchange old ones for new ones," etc.). Afrikaans does not appear to have induced with in this quotation (Joubert 1992 gives - vir - ruil, - vir - verruil, - vir - inwissel, - vir - uitwissel, and - deur - vervang, that is, with vir 'for' or deur 'through'). Nor is Afrikaans - in die plek van - stel 'to substitute $x$ for $y$ ' relevant here. One of the following, therefore, must be correct: [1] De Klerk was misquoted; [2] he had replace with in mind at the moment (in which case, this would be a slip of the tongue); [3] this is an idiolectalism in his English (in which case it is presumably induced by replace with); or [4] this is a South African English usage of wider currency.

\section{gnarly surfing}

Discussion: Lighter et al. 1994 notes that the 1977 edition of Filosa's Surfing Almanac, p. 186, lists the surfers' term gnarly and defines it as meaning 'big, hairy surf' in South African English and 'challenging surf, but ridable and fun' in American English. Since non-professional dictionary-makers are usually unaware of the lexicographical convention that, if possible, the definiens should belong to the same part of speech as the definiendum (the exception being definienda which are particles, since it is usually hard, if not impossible, to define, say, a conjunction by a conjunctive phrase), we cannot be certain that gnarly is a noun in South African or American English surfing terminology (as a literal interpretation of Filosa's definitions would imply). Either, then, the definitions need revision or, if they are correct, gnarly is elliptical ("gnarly surf $>$ gnarly).

See over the falls below for further discussion.

governor See administrator above. 
imfece

Discussion: A review in The New York Times of a concert of South African music in New York City spoke of "ankle imfece rattles," without any graphic illustration or further details. Clearly, we need more information before a good definition can be written.

ingungu 'African friction drum made from a gourd'.

Discussion: The foregoing definition, which I inferred from a review in The New York Times of a concert of South African music in New York City, may be too narrow or too broad. See mbube below for discussion of the problem.

\section{in-waiting}

Discussion: I first saw in-waiting in the collocation the government-inwaiting 'the Blacks of South Africa who expect to assume power after universal suffrage is enacted and elections are held in the country' (the source was an American publication). It seems to have been suggested by government-inexile and lady-in-waiting (though in a different sense of wait). "Governmentin-the-wings would have been a better choice. A quasi analog is Israeli Hebrew hamedina shebaderech (literally 'the state that is on the way'), which refers to the Jewish institutions founded in the Land of Israel before 15 May 1948 in anticipation of Jewish statehood there, which was declared on 14 May.

So far so good, but later the American media referred to Nelson Mandela as the president-in-waiting, from which it became clear that the entry should not be for the government-in-waiting but for in-waiting (with government-inwaiting and president-in-waiting as two frequent collocations illustrating the word). The question is thus whether those are the only two collocations in which in-waiting in this special sense is used or there are more; and since I found it only in American sources, we would also want to know whether it is used in South African English (if it is, the next question would be whether it was coined in that variety).

The foregoing reminds us of an entry in Branford and Branford 1991 headed State President. Since the adjective state / State in that sense is used in any number of other collocations too (like the state departments, state agencies, the State Library, the State Printer, and the State Security Council), this use of the word is not unique to State President. Hence the entry should be for state / State, with State President merely as one of the examples (the etymology being "literal translation of Afrikaans staat- / Staat-").

See mbube below for further discussion.

isigubu 'African cylindrical drum made from a hollow log'.

Discussion: The definition, inferred from a description of the instrument in a review in The New York Times, may be too narrow or too broad. See mbube below for discussion of the problem. 
isicathamiya 'kind of Zulu entertainment, which includes music, singing, and dancing' [< Zulu, lit. 'stalking; tip-toeing', so called because this entertainment, which arose in rural areas, originally included hard-stomping dance steps, but when it was brought to urban areas, neighbors complained of the loud noise and the dancing was consequently made softer].

Discussion: The definition, inferred from a review in The New York Times of a concert of South African music in New York City, may be too narrow or too broad (see mbube below for discussion of the problem). The etymology, taken from that review, needs to be verified (newspapers and other popular prints often contain etymologies which are partly or fully wrong).

it

Discussion: It is in certain instances used as the object of a verb in a main clause as the anticipation of a subordinate clause beginning with that, to, or of, as illustrated in these sentences: "I think it likely that we will be able to...," "I believe it likely that she will...," "I suppose it wise not to leave just when...," "I deem it justified not to take any further measures," "I find it prudent at this time not to attempt any...," "I believe it my duty to tell you that...," "They're making it hard to believe that anyone could...," "We think it well not to say...," "He left it to us to find...," "He took it into his head to tell them that...," "You may rely on it that nobody will ever...," "She saw to it that nobody leave without...," "I want to make it clear that you cannot...," and "They made it a point of never going..." So far as I am aware, all of those usages are standard English and omission of it would be a non-native error.

The New York Times of 3 May 1994, p. A16, quotes F.W. de Klerk as saying "I should like to make clear that I believe that my political task is just beginning." An American ear expects would rather than should and make it clear that.... Since the quotation is taken from a speech which De Klerk made partly in English and partly in Afrikaans, but the newspaper gave the entire speech in English (without indicating which part is original and which translated), it is not clear whether it was De Klerk or the Afrikaans-English translator who omitted it. In any case, the omission seems likely to be an Afrikaansism. How widespread it is remains to be determined.

Use of it where American English would not have anything is also found: in his inaugural address (10 May 1994), Nelson Mandela said "We understand it still that there is no easy road to freedom" and "We know it well that none of us acting alone can achieve success."

jingo offensive $n$. and adj. 'Black'.

Discussion: This word was found in a possibly unreliable source, Its form, meaning, and currency thus need to be scrutinized.

Remark from D.C. Hauptfleisch: Ek ken nie jingo in Suid-Afrikaanse Engels in die betekenis 'Black' nie, ook nie in Afrikaans nie. Dié woord is in Suid-Afrikaanse Engels direk uit Engels ontleen (sien Compact Oxford Dictio- 
nary8, 1990, vir sy Engelse betekenisse en by jingo!). In Afrikaans het jingo onder meer die betekenis gekry van ' $n$ sterk Engelsgesinde Suid-Afrikaner'.

Discussion: Having mislaid the quotation, I can recall only that it was in English. In light of D.C. Hauptfleisch's remark, my guess is now that the word was used there to mean 'very pro-British South African' and that the etymology is probably: < Afrikaans jingo 'idem' = shortening of English by jingo!.

\section{Kaffir}

Discussion: Here the problem is not meaning or origin but currency. As an offensive word, Kaffir had seemed to me, as an outsider, to be limited to White English, though Clines 1994a: A6 has: "As mixed-race supporters openly denounce blacks with the shouted racist epithet 'kaffirs!' at his rallies, Mr. Kriel, among the least penitent of the ruling old guard, accepts the cheers and warns of blacks' taking power." Apparently, then, the word is of wider currency than I had thought. See mdube below.

KwaZulu See Capetown above.

main. E.g., "main ou," "main plan," and "That's really main, man."

Discussion: This word (given in Hanks 1981) needs to be defined and etymologized (it is presumably from Afrikaans).

mbube 'harmonies sung by male Zulu singers'.

Discussion: The definition, inferred from a review in The New York Times of a concert given by South Africans in the United States, may be too narrow or too broad. That is, this particular concert may well have featured male Zulus, though such harmonies may also be sung by females, non-Zulus, or non-Zulu females (in which case the definition is too narrow). Or, perhaps these are special types of harmonies or special types of singers (in which case it would be too narrow). Since the reviewer, an American, presumably did not know the word before attending the concert, his definition is probably based on what HE saw and heard on THAT PARTICULAR occasion, which may not have provided him with enough information to define the word correctly.

We thus have a problem analogous to the ones raised at in-waiting, Kaffir (both above). The fewer quotations we have, the less we may see of the total picture, whether it is a question of degree of productivity (as with in-waiting), meaning (as with mbube), or currency (as with Kaffir).

motor city and shack town

Keller 1994j calls Port Elizabeth "this motor city on the Indian Ocean" and mentions a "shack town." Since the nickname of Detroit, Michigan, is the Motor City (because American automobile manufacturers have their headquarters there), Keller is an American, and I have till now not found Port Elizabeth referred to as a motor city or as the Motor City, it is reasonable to assume that 
motor city and the Motor City are probably American usages only. If so, Keller was merely applying an Americanism to a South African situation.

In shack town we presumably have just the opposite. American English has shanty town, not shack town. It is thus reasonable to assume that shack town is probably a South African usage.

The word probably in both of the preceding paragraphs is important: we would not want to remove it before investigating further. See also Old Port Elizabeth in section 2 .

Mr. Dube 'personification of the male Black South African' [Dube is a frequent Black South African family name].

Discussion: At least since April 1994, the South African Defense Forces, in an effort to recruit Blacks, have published advertizements in the newspapers with a collage of tanks and jets accompanied by the slogan "Mr Dube, these belong to you." We would want to know whether this lexeme is limited to such advertizements.

Mrs. Mandela's football team informal.

Discussion: It was unclear from the passage in The New York Times where this item was found (exact reference mislaid) whether the sense is 'Winnie Mandela's bodyguards', 'Winnie Mandela's hit squad', or 'Winnie Mandela's bodyguards and hit squad', though another source made the sense clear: "[...] when she did return to Johannesburg, in 1985, she began the most controversial phase of her life. She surrounded herself with a group of young toughs who masqueraded as a soccer team but were in fact a private gang who guarded her and did her bidding" (Sparks 1994: 62). Although the label informal easily suggests itself from the literal meaning of the lexeme, we would also want to know whether it has any additional labels (humorous? sarcastic?).

murumbu 'pot-shaped African drum'.

Discussion: The definition, inferred from a review in The New York Times of a concert of South African music in New York City, may be too narrow or too broad. See mbube above for discussion of the problem.

over the falls surfing 'caught in the curl of a wave and sucked over with the wave as it crashes'.

Discussion: According to Lighter et al. 1994 (whence the definition), this lexeme is attested as a surfers' term in South African English since 1977 and in American English since 1981. The earliest quotations on hand are thus too close in time to allow us to decide in which direction influence has probably gone (the possibilities are at least American English < South African English; South African English < American English; South African and American English < some other variety of English). The fact that American English and South African English share two very specific surfers' terms (the other one is 
gnarly, discussed above) suggests that they may share more. Since the only other English-speaking country where surfing is widespread is Australia, Australian English may be the "some other variety" suggested as a possible source.

Surfing contests between people from different countries and the circulation of surfing magazines of one country in others are the channels by which such terms may easily pass from one variety of English to another.

A study of South African surfers' terminology, in whatever languages it exists, with intra- and extra-South-African comparisons, would be useful. Whether any South African English surfers' terms are of Afrikaans origin remains to be seen.

pah! pah! pah!

Discussion: Allen 1994 quotes a 68-year-old Sowetan: "I saw kids running around in the street and getting shot and killed by police. The police would come - pah! pah! pah! - shoot the kids, then take them away." The American equivalent is bang! bang! bang!. Is this a nonce form? An idiolectalism? A Black South African English usage? A general South African English usage? Is it derived from an African language?

\section{Peace Greetings See unrest area below.}

post-apartheid adj. E.g., "What will post-apartheid South Africa look like?"

Discussion: Although the word has appeared several times in American sources and thus looks established both in American and South African English, it is not clear from the quotations when, precisely (if at all), the postapartheid era began: with the election of Nelson Mandela to the presidency? when the previous government abolished this or that law enacted under apartheid? The words if at all are important because, unless this is a legal term (which is does not appear to be), people may use it without precisely defining the time from which it applies. Thus, it is clear that it does not apply to the time when apartheid was in full force and it does applies to the period beginning with the April 1994 elections, but what about the intervening stretch of time?

premier See administrator above.

the Presidency 'official residence of the State President (in Pretoria)'.

Discussion: Since the United Kingdom does not have a president, this cannot be a usage adopted from British English. American English does have presidency, but since it is used only in an abstract sense, it is not likely to be the source of the South African English word. This, then, must be a South African innovation. 
Since the South African government bureaucracy has been largely Afrikaans-speaking, this must be a translation of some Afrikaans term (and, in any case, Afrikaans must have an equivalent, which, since neither the Netherlands nor Belgium has a president, must be at least an Afrikaans neosemanticism if not an Afrikaans neologism rather than an inheritance from Dutch).

Since English -cy often corresponds to Afrikaans -sie (< Early Afrikaans -tie < Dutch -tie), the Afrikaans word in question is presumably die Presidensie. If so, South African English the Presidency is an anglicization of the Afrikaans word (rather than an extension of meaning of English presidency).

The Afrikaans word has a history too: it is presumably modeled on Dutch die residentie 'the royal residence' and its semantic development appears to be paralleled by that of South African English drosdy 'magisterial district of the landdrost's (q.v.) jurisdiction; the headquarters, and home of the landdrost (q.v.), the residency, also house'.4 The word is derived from Dutch drostdy, which appears to have only the first meaning. From the appearance of residency in that definition it would seem that this word is used in a special way in South African English, a subject we leave for a future occasion. ${ }^{5}$

After the foregoing was written, I learned that the building erected in Bloemfontein in 1885 to serve as the official residence of the president of the Orange Free State is now called the Old Presidency. That confirms my assumption that we should look to Afrikaans for the source of presidency in the sense under discussion here, yet since the official language of the Orange Free State was Dutch, we may suppose the existence of South African Dutch *die Presidentie in this sense. The etymological chain thus appears to be a bit more complicated: South African English the Presidency is an anglicization of Afrikaans die Presidensie and/or South African Dutch die Presidentie; the Afrikaans word is derived from the South African Dutch word; and the latter is modeled on Dutch die residentie.

\section{prevail}

Discussion: Bryson 1994 quotes Nelson Mandela: "We will continue prevailing upon him to accept the honor we are prepared to give him." This use of

4 Those definitions, taken from Branford and Branford 1991, can be rewritten succinctly and more accurately as 'district under the supervision of a landdrost' and 'landdrost's home; landdrost's headquarters'.

5 How far back one would have to delve to elucidate the entire history of residency is not clear. For whatever it may be worth, let it be noted that J.A. Wilson's translation of "The Story of Sinuhe," which was written by an Egyptian during the second half of the twentieth century B.C.E., includes the term Residence City: "The messenger who went north or who went south to the Residence City tarried with me, for I used to make everybody stop over" (Wilson's translation may be found in Pritchard 1950: 18-22). 
prevail is in principle acceptable ("I've always prevailed on them, I'm prevailing on them now, and I'll prevail on them in the future," etc.), but Mandela did not want to sound boastful. What he meant to say was "We will continue to try to prevail upon him [...]." This is presumably either a slip of the tongue, an idiolectalism, or a misquotation.

provincial administrator See administrator above.

provision $v$. 'to supply with something'. E.g., "Judge Johann Kriegler, the head of the electoral commission, said the group was 'satisfied that because of its difficulties in provisioning those areas, the voters there have not had a fair and free opportunity to express their views'" (Noble 1994b).

Discussion: The verb provision is general English, but, at least nowadays, it seems to be used mostly with respect to food (and, even in that sense, it is infrequent at least in current American English). If the word is current in British English in a general sense, it is not a South-Africanism. This, then, is an item to be checked with speakers of British English: would they use the word as Kriegler did?

puffadder Namaqualand 'mottled greenish sausage-like springbok bowel stuffed with pluck'.

Discussion: An American source gave this usage for Namaqualand, but that does not necessarily mean that it is limited to that area. Its spatial currency thus needs to be determined.

put under criticism 'to level criticism at, criticize'.

Discussion: This usage was heard one time, from Nelson Mandela. A slip of the tongue? An idiolectalism? A Black South African English usage? A more widespread South African English usage?

rand millionaire 'person who is worth at least one million rand'.

Discussion: Since Afrikaans presumably has an equivalent, we would want to know which language borrowed from which, if that is still ascertainable. See securocrat below for the same question.

\section{[reflexive pronouns]}

Discussion: A Zulu interviewed on American television in April 1994 said "If they attack us, we'll defend us." With just a single quotation for us in the sense of 'ourselves', we would consider this to be a slip of the tongue, an idiolectalism, or a sporadic non-nativism. A few days later, however, a native speaker of Afrikaans interviewed on American television used us in that very same way. This item, then, may be more than a sporadic non-nativism in South African English. 
resources

Discussion: Keller 1994d quotes Nelson Mandela as saying "He's alarmed that we have to devote so much resources to blacks." Resources being a count noun, we expect many. A slip of the tongue? An idiolectalism? A Black South African English usage? A more widespread South African English usage?

say vs. tell

Discussion: When to use say and when tell is probably not completely reducible to rules. That non-native speakers of English make mistakes is clear from examples like "We tell each other, let's move away, maybe it's a bomb" (Cherry van Heerden, 18 years old, describing to a reporter how he and a friend near where a bomb went off decided to move away just before the explosion [Keller 1994e: A1]). To an American ear, "We said to each other" is the normal wording (also, the speaker's use of the present tense instead of the past does not sound native). South Africans' use of say and tell thus needs study.

securocrat 'hawkish member of the military-security establishment'. E.g., "For one thing, Mr. de Klerk, unlike his predecessor, P.W. Botha, was not a 'securocrat.' He has never had the insider knowledge of the security forces, or their full trust" (Keller 1994b). Also attributively, e.g., "the securocrat establishment" (Sparks 1994: 76).

Discussion: The definition needs review (for one thing, is 'obsessed with a Communist threat to South Africa' an essential part?). Was this word coined spontaneously in South African English or is it a translation from Afrikaans? See rand millionaire above for the same question.

sexuality education 'sex education'.

Discussion: A South African quoted in an American publication used this term one time. The definiens is the British and American English equivalent. A nonce form? A widespread usage?

shack town See motor city above.

shiwaya 'African vessel flute made from a hollow fruit shell'.

Discussion: The definition, inferred from a review in The New York Times of a concert of South African music in New York City, may be too narrow or too broad. See mbube above for discussion of the problem.

Some more! 'See you!'.

Discussion: This lexeme (given in Hanks 1981) needs to be etymologized. 


\section{speak to despatches}

Discussion: The term was heard once on American television from a South African policeman or soldier, but with no definition. It being possible that I misheard him, the entry head may not be accurate.

Spear of the Nation 'anti-apartheid underground of the African National Congress'.

Discussion: This name is presumably translated from some African language (Xhosa?). Its etymology thus needs to be investigated.

special voter 'South African allowed to vote on the first day of the panracial elections, 27 April 1994 (= any South African citizen abroad, any former South African citizen abroad, any nurse, any member of the police force, any elderly person, any ill person, any disabled person, or any non-violent prisoner)'.

Discussion: The definition offered here is based on reports in The New York Times and on American television, where several definitions, none pretending to be exhaustive and each partly different from the others, were given. The exact definition may easily be gotten from the Electoral Act regulating the elections of April 1994.

sport

Discussion: Keller 1994g writes: "'Now we can sing Die Stem at sport without being ashamed,' said Gary Brownlee, a 16-year-old student at King Edward High School here." In current American English, sports events would probably be most usual here. This use of sport is presumably general in South African English, where it may be of British English origin. If so, it is not a South-Africanism.

\section{stand on line}

Discussion: Mustain and Allen 1994 quote a White South African, probably a resident of Johannesburg: "'Where I voted, there were blacks and whites and colored and the mood of everyone was, "Let's get rid of the crap in this country and just live together as equal people,"' said Raymond Gaddin, the 54year-old owner of a camping-supply store. 'People were standing on line and laughing and going to get snacks for each other,' he added. 'When I got home, I went to the synagogue and prayed for the miracle we have received - an election that was like a revolution, but without any violence'."

British English has the verb phrases form a queue, queue, queue up, and stand in a queue. Most varieties of current American English have form a line, get in line, and stand in line. New York City English too has form a line, but it distinguishes get in line and get on line, as well as stand in line and stand on line: for example, to ask people to get in line in New York City English means (as it does in other varieties of American English) to ask people already standing in a line to make it straighter (so that they will be standing in 
line), whereas get on line (which seems to be found only in New York City English) means 'to queue up', and stand on line (likewise apparently limited to New York City) means 'stand in a queue'.

So far as I can tell, South African English follows British English. If so, we expect Gaddin to have used stand in a queue. Stand on line is highly unusual . coming from a South African (the possibility is remote that he is a transplanted New Yorker). My guess is that Mustain and Allen, both of whom are speakers of New York City English, felt that their readers would not understand stand in a queue and therefore silently replaced it by stand on a line. 6

We would thus have here a case similar to boss (above), with the difference that here the change from a South African to an American English form was deliberate. For safety's sake, South African usage may be checked and Gaddin himself could be contacted.

state-of-the-nation speech 'address by the State President to the South African people on the state of the country, with an outline of the government's intended program (first delivered by Nelson Mandela on 24 May 1994)' [modeled on American English State-of-the-Union message / State-of-theUnion address].

Discussion: Since the State-of-the-Union message is mandated by the United States Constitution (Article II, Section 3), we would want to know whether its South African counterpart is mandated by South Africa's Interim Constitution. Keller 1994h, which is devoted to the speech, is silent on that point.

the third force 'the conspiracy at the top levels of the security forces in years just before the elections of April 1994 to sabotage the transition to majority rule'.

Discussion: The definition given above is more or less the one in Keller 1994a, but since a force is not a conspiracy, the definition is not quite accurate, though we can easily amend the wording to 'group of conspirators at the top levels...'.

According to Keller 1994c, "Nelson Mandela has long argued that a 'third force' of high-ranking security officers was stoking the factional violence between his African National Congress and the Zulu nationalists of the Inkatha Freedom Party, as a way of prolonging white rule." From "long argued" we infer that a much earlier quotation than Keller 1994a can be found. If Mandela coined the term, he coined it in English. If he did not coin it, it must have either originated in South African English or be a translation of the corresponding Afrikaans term. quotation marks may be seen from the fact that different newspapers may report different versions of the same utterance. 


\section{tilapia}

Discussion: The first quotation for this word in the second edition of the Oxford English Dictionary is from "A. Smith Illustr. Zool. S. Afr.: Pisces 5," published in 1849. Since I do not have access to Smith's book and it is not listed in the bibliography of the Oxford English Dictionary, it may only be presumed that this is Andrew Smith, a Britisher who directed the Expedition for exploring Central Africa (1834-1836) and whose diary of the expedition has been published several times. Tilapia is Smith's Modern Latin coinage, which, the second edition of the Oxford English Dictionary says, may be composed of two Classical Greek words. Whether the fact that the tilapia is found in South Africa and is first mentioned, so far as is known, in a work about that country is enough to warrant consideration of tilapia as a South-Africanism depends on how South-Africanism is defined.

tri-partheid 'investment of an American firm in both a Black and a White South African firm' [catachrestic blend of tripartite and apartheid].

Discussion: The earliest quotation I have is from Lavan 1994, which suggests that this word was coined by Wallace Ford, an American. Tri-partheid is infelicitous because apartheid is irrelevant and tripartite does not mean what the coiner, whoever it may have been, thought it does. If the coiner was a South African and not Wallace, we have a South-Africanism. If it was Wallace or any other non-South-African, we have a non-South-Africanism of eminently South African interest. The problem is thus determining the topolectal status of the word. Tri-partheid and Bantu knot (above) are similar in certain ways.

\section{unrest area 'area of unrest'.}

Discussion: The American press reported on 29 March 1994 or thereabouts that Hernus Kriel, then South Africa's Minister of Law and Order, had declared certain parts of the country to be "unrest areas." Though American English does have rest area (designating a place on a highway where drivers may stop to rest), to an American ear area of unrest sounds much better than unrest area. Since Afrikaans has many compound nouns consisting of two nouns (joined in some cases by s) which correspond to English noun phrases consisting of a noun, a preposition, and another noun (e.g., Afk. dankbetuiging = Eng. expression of thanks, Afk. sweetdruppel = Eng. bead of sweat, bead of perspiration, and Afk. waarnemingsvermoë = Eng. power of observation), we may be certain that this is a literal translation from Afrikaans, especially since Afrikaans is the native language of Kriel and of many of the top officials of his ministry at the time. It might seem curious that native anglophone American reporters accepted unrest area, but on second thought they presumably wanted to quote Kriel verbatim. Here, then, all that remains to be done is find the Afrikaans etymon.

After the foregoing was written, I saw a National Party poster with the words Peace Greetings (April 1994) and noticed stream bed in Branford and 
Branford 1991, where poort is defined as 'narrow pass or defile through mountains usu. along a stream bed'. Again, the construction with of would come more naturally to my lips (Greetings of Peace, bed of a stream) and I am now more inclined than ever to think that Afrikaans accounts for certain noun + noun collocations in South African English which in other varieties of English would be unusual.

\section{volkstaat}

Discussion: Branford and Branford 1991 define the word as "White" republic envisaged by the Afrikaner Weerstandsbeweging ( $A W B$ ) and other rightwing bodies'. As the aspirations of that movement change, the current definition will too. Just before the elections of April 1994, "'White" republic' seemed to have given way to 'autonomous Afrikaner province'. After the elections, the latter definition appears to have given way to 'autonomous Afrikaner area'. Perhaps the word will eventually refer to Orania.

A caption in The New York Times of 28 April 1994, p. A14, reads: "Bothaville: In a city considered 'volkstaat,' or white country, a lone black woman stood in line to vote for the first time. She said she could not give her name because it would violate the rules of the polling place." Since no South African is quoted and the caption-writer was presumably a speaker of American English, use of volkstaat as a mass noun here is likely to be an American English nonce form, especially since it is immediately followed by the mass noun white country. Cf. Marlboro country, in American advertizements for Marlboro cigarets, which the caption-writer may have had in mind.

\section{volkstaater}

Discussion: The current meaning is 'supporter of the idea of a volkstaat' (however volkstaat is defined), but if such an entity is established, volkstaater would presumably come to designate a native and/or resident of it. The word is presumably of Afrikaans origin.

zippo 'homemade shotgun'.

Discussion: The difficulty does not seem to be with the definition but with the etymology. At first I thought of "< Zippo, brand name of a cheap, expendable cigarette lighter" but later recalled that American English slang has zip gun 'homemade pistol' (at least since the 1950s). Is zippo from Zippo? Is it based on zip gun? Are both possibilities correct?

zenick

Discussion: The quotation (mislaid) says that zenick and suricate are synonyms. That needs to be verified. Whether the word is a South-Africanism needs to be determined and it requires an etymology. 


\section{Conclusions}

The foregoing material was gathered in the course of about a year and a half by someone who has access to few South African sources and who devotes only a small part of his research time to South African English. Even if we discount the items that would have to be discarded if they turned out not to be SouthAfricanisms, the fact that so much was collected with so little means suggests that an intensive, systematic comparison of British English and South African English would turn up a myriad of South-Africanisms hitherto unrecorded or, at least, recorded but not identified as South-Africanisms.

The material appears to suggest that an outsider who occasionally peers into the fishbowl may contribute by suggesting possible candidates for inclusion in a differential dictionary and may ask the right questions but he lacks much of the knowledge needed to determine the synchronic status of the items (meaning, register, currency, etc.). What's more, it is by no means certain that all of the items in section 2 could go into a dictionary without further treatment. On the other hand, the fact that many dictionaries compiled by native speakers are bad shows that native competence is no guarantee of success either.

If all researchers should exercise great caution in using primary and secondary sources, that is doubly true of outsiders and triply true of outsiders using outsiders' sources (see boss and stand on line, both in section 3). Definitions written by non-linguists should be used critically: non-linguists may underdefine, they may overdefine, they may write definitions which do not belong to the same part of speech as the definienda, and they may misdefine in others ways (see the third force, in section 3 , where it is noted that a force is not a conspiracy).

The material also shows that the better one knows a language, the easier one can spot deviations from the norm.

With respect to etymology, whether one is or is not a native speaker is of secondary importance. Here, training in historical linguistics and familiarity with the inner and outer history of the languages involved are what counts the most. The fact that native speakers contrive and propagate folk etymologies shows that native competence is no guarantee of success in etymological research.

Outsiders may thus have a better preliminary view of the fishbowl than insiders, but insiders are needed to describe its current topography accurately - and neither insiders nor outsiders are necessarily better equipped to study the history of the fishbowl.

The time is long past when Roger Bacon (1214?-1294?), "the Admirable Doctor," could boast that he knew everything that the Christian world felt was known and worth knowing. Today, teamwork is the only way of compiling a good dictionary of any size. 
Three Yiddish sayings: a shayles-khokhem iz a halbe tshuve 'a wise question is half an answer', alts in eynem iz nito ba keynem (= Latin non omnia eidem dei dederunt and non omnia possumus omnes), and fir oygn zenen beser vi tsvey por briln 'four eyes are better than two pairs of eyeglasses'?

\section{References}

Allen, Michael O. 1994. "Visit to Soweto: A tormented past, uncertain future: Poverty, violence crowds out hopes." Daily News, New York, 10 April 1994: 37.

Branford, Jean. 1980. A Dictionary of South African English: New Enlarged Edition. Cape Town: Oxford University Press [rev. Hanks 1981].

Branford, Jean with William Branford. 1991. A Dictionary of South African English. Fourth edition. Cape Town: Oxford University Press [rev. Gold 1992].

Bryson, Donna. 1994. "'Incensed' Zulus to fight on, sez leader." Daily News, New York, 10 April 1994: 37.

Clines, Francis X. 1994a. "De Klerk's Party Is Driving Wedge Between Nonwhites." The New York Times, 18 April 1994: A1 and A6.

Clines, Francis X. 1994b. "South Africa Slips Quickly Into Parliamentary Routine." The New York Times, 8 May 1994: 10.

Clines, Francis X. 1994c. "South Africa's Test Now: Grass-Roots Democracy." The New York Times, 21 May 1994: 6.

Gold, David L. 1986. "Two Desiderata for Lexicography: Allolingual and Allotopolectal Collaborators and the Philological Review (With examples from Canadian, Bahamian, and South African English)." Dictionaries 8: 112-145.

Gold, David L. 1992. Review of Branford and Branford 1991. Lexikos 2: 85-136.

Gold, David L. 1993. Review of Joubert 1992. Lexikos 3: 303-313.

Hanks, Patrick. 1981: Review of Branford 1980. English in Africa 8: 73-85.

Joubert, P.A. 1992. Bilingual Phrase Dictionary / Tweetalige Frasewoordeboek (E-A). Cape Town: Tafelberg [rev. Gold 1993].

Keller, Bill. 1994a. "Inquest Finds South Africa Police Aides Zulus in Terror Campaign: Testimony Produces a Quandary for de Klerk." The New York Times, 19 March 1994: 1 and 7.

Keller, Bill. 1994b. "War to Keep Apartheid Spawned Terror Network." The New York Times, 20 March 1994: 10.

Keller, Bill. 1994c. "Election Worries: In South Africa, A White 'Third Force' of Violence Is Confirmed." The New York Times, 20 March 1994, section 4: 2.

Keller, Bill. 1994d. "Mandela and de Klerk Square Off on TV." The New York Times, 15 April 1994: A10.

I would appreciate hearing from insiders who can answer any of the questions asked in this article. My thanks go to Solly Rechtman, who brought a number of South-Africanisms to my attention. 
Keller, Bill. 1994e. "More Bombings Rattle South Africans." The New York Times, 26 April 1994: A1 and $\mathrm{A} 8$.

Keller, Bill. 1994f. "Blacks Seizing Their Moment: Liberation Day." The New York Times, 28 A pril 1994: $A 1$ and $A 14$.

Keller, Bill. 1994g. "Whites in South Africa Find The World Has Not Ended." The New York Times, 12 May 1994:. A1 and A8.

Keller, Bill. 1994h. "Mandela Describes the Hard Work Ahead." The New York Times, 25 May 1994: A8.

Keller, Bill. 1994i. "Mandela Is Mr. Nice Guy, Irking Some Allies." The New York Times, 23 June 1994: A11.

Keller, Bill. 1994j. "Next for the New South Africa: Potholes and Taxes." The New York Times, 9 July 1994: 3.

Lavan, Rosemary Metzler. 1994. "Cautious, but optimistic on S. African prospects." Daily News, New York, 29 A pril 1994: 45.

Lighter, J.E., with J. Ball and J. O'Connor. 1994. Random House Historical Dictionary of American Slang. Vol. 1 (A-G). New York: Random House.

Mustain, Gene and Michael O. Allen. 1994. "Free at Last: Bright New Day: We're also set free by vote, many whites say." Daily News, New York, 3 May 1994: 4.

Noble, Kenneth B. 1994. "South Africans Extend Voting To Fourth Day." The New York Times, 29 April 1994: A1. This is a revised version of an interview which appeared in Lexikos 3: 227-258.

Pritchard, J.B. (Ed.). 1950. Ancient Near Eastern Texts Relating to the Old Testament. Princeton: Princeton University Press.

Rosenstein, Roy S. 1993. "Broadening the Perspectives of South African English and Afrikaans Research (an Interview with David L. Gold on His Work in These Fields)." Lexikos 3: 227-258.

Sparks, Allister. 1994. "Letter from South Africa: The Secret Revolution." The New Yorker, 11 April 1994: 56-78. 